TITLE:

\title{
CELLULAR SITES OF
} IMMUNOGLOBULINS(Abstract_要 旨)

$\operatorname{AUTHOR}(\mathrm{S})$ :

Chen, Shi Ze

\section{CITATION:}

Chen, Shi Ze. CELLULAR SITES OF IMMUNOGLOBULINS. 京都大学, 1973, 医学博士

ISSUE DATE:

1973-03-23

URL:

http://hdl.handle.net/2433/219932

RIGHT: 


\section{【131 】}

氏 名

学位の種 類

学位記番号

学位授与の日付

学位授与の要件

研究科・専攻

学位論文題目

論文調查委員
陳
チン

世

澤

医学 博士

医 博 第 431 号

昭和 48 年 3 月 23 日

学位規則第 5 条第 1 項該当

医学研究科病理系專攻

\section{CELLULAR SITES OF IMMUNOGLOBULINS}

（免度グロブリン含有細胞の分布について）

(主 查)

教授深瀬政市教授花岡正男教授委川修

\section{論 文内容の 要 旨}

1）免疫グロブリンは性質の異なる幾種類かのものが存在している。最近これを heavy と light polypeplide chain 構造にもとづいて分類することが可能となった。Heavy polypeptide chain は各グロブリ ンに特有の構造部分があり，それぞれ $\gamma, \alpha, \mu, \delta$ 抢よび $\varepsilon$ chain と呼ばれ， $\gamma, \alpha, \mu, \delta$ 扤よび $\varepsilon$ chain を有する免疫グロブリンをそれぞれ $\operatorname{IgG}, \operatorname{IgA}, \operatorname{IgM}, \operatorname{IgD}$ 及び $\operatorname{IgE}$ 等に分類している。又 light polypeptide chain は各グロブリンに共通で，それぞれ kappa chain 及び lambda chain の二種類があり， 上記免疫グロブリンを kappa chain 及び lambda chain の存在により Type I と Type II に区別し得 る。

著者は kappa 或いは lambda 型 Bence-Jones 蛋白尿を12時間活性炭により吸収し，珪酸塩で滤過後， 40\%飽和硫安分画で Crude globulin を得，この Crude globulin をDEAE cellulose column 分画によ り分離し，第一のピークを蒐集し，更にこの分画を sephadex G-100 で再精製して第二のピークから純 粋の Bence-Jones 蛋白 (kappa 及び lambda 型) を得た。又人血清から DEAE cellulose column 分画 で純粋な IgG を分離し，この IgG を Porter (1659) の方法に従い, パパインにより消化し, Hiao と Putnam (1961) の方法で CM cellulose column で分画し gamma chain ( $\gamma^{-}, \mathrm{Fc}$ ) を得た。

以上精製採得した kappa $(\mathrm{k}-)$, lambda ( $\left.\lambda^{-}\right)$及び gamma $\left(\boldsymbol{r}^{-}\right)$各 chain 抗原は Carl-Zeiss PNQ II spectrophotometer $280 \mathrm{~m} \mu$ で吸収度を調べ, 更に免疫電気泳動法で, その抗原単一性を確認した後, そ れぞれを明攀沈澱法で家鬼に免疫し，kappa， lambda 及び gamma 各 chain 抗原に対する抗血清を得た。

抗血清はそれぞれ Ouchterlony 寒天板, 濾紙電気泳動法, 免疫電気泳動法により抗血清の免疫学的性 質を検討し，污染物の無いことを確認した後，FITC 及び TRITC で標識し，螢光抗体液を作成した。 又各螢光抗体液はそれぞれ相互に，他の二種の抗原を加えて $37^{\circ} \mathrm{C} ， 30$ 分間吸収を行なった上で切片の反 応に用いた。

検索にもちいた組織は29歳より73歳に至る男女患者の脾臓（8例）と腸間膜リンパ節（11例）を，生検 


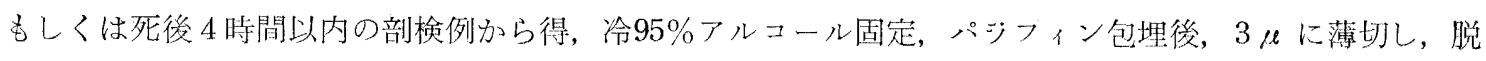
パラフィン後，以上の精製した抗血清で二層染色し，䖝光顕微鏡下に模索した。

kappa, lambda 及び gamma chain はほぼ同様に形質細胞及びリンハ球系紏胞で産生されている。 Gamma chain 産生細胞は kappa ふ，または lambda，いずれかの light chain をもち，両者 (kappa と lambda chain）を一個の細胞が同時にもつことはない。kappa と lambda chain の出現頻度の比率は kappa chain が57 68\%, lambda chain が30 43\%で, kappa chain の方が多い。また light chain の 一種 (kappa 或は lambda) と gamma chain との相関関係を螢光抗体法二層染色法で観察してみると, gamma chain 含有細胞 (即ち gamma chain 及び gamma chain + kappa chain 産生細胞, 或は gamma chain 及び gamma chain+lambda chain 産生細胞）は螢光発出細胞の約半数を示している。このこと は，免疫グロブリン産生細胞の半数が IgG を産生しているともいえよう。

上記免疫グロブリン産生細胞の産生部位をみると, 脾臟では赤䯣に, リンパ節では髄質に, それぞれ全 般に散見されるのが認められる。しかしながら, 同一時期, 同一芽中心に kappa と lambda chain 産生 細胞が同時に存在することはなかった。

2）人胃腸管の粘膜固有属には豊富に形質細胞が存在し，これが抗体産生上極めて重要な役割を占める ことが最近の免疫学の進歩により明らかになって来た。即ち新生児期, 特に骨髄にも形質細胞の存在しな い時期にも既に回腸及び虫垂には形質細胞が存在し，新生児期の免疫に当っている。更に又最近，螢光抗 体法により， IgG， IgA， IgM, IgD 及び $\operatorname{IgE}$ 産生細胞の分布も明らかにされて来た。

著者は，人虫垂の炎症時に於ける免疫グロブリンの分布の变化を螢光抗体法を用いて検索した。即ち， 手術により急性炎症として切除された虫垂46例を病理組織学的に Therkelsen の分類に従い早期, 進行 期，化膿期及び慢性化期に分類し，各病期に於ける IgG，IgA， IgM，及び共同である kappa と lambda chain の分布を検索した。

IgG は人プール血清を硫安処理により分画, IgA は人 IgA 型骨䯣腫症例の血清を Starch gel electrophoresis により分画, kappa 及び lambda chain はそれぞれ kappa 型及び lambda 型 Bence-Jones 蛋 白尿から分画後, 何れも, DEAE cellulose column 分画及び Sephadex G-100 column 分画を用い精 製した後, 家鬼に免疫して，それぞれの抗血清を作成し，FITC 及び TRITC で標識し遊離色素を充分 に除去した。これらの抗血清は何れも免疫電気泳動法により免疫学的に純粋であることを確認した後, 更 に使用直前に相互に吸収して使用した。

標本の固定は $95 \%$ 冷アルコールで行ない, パラフィン包埋後, 薄切, 脱パラフィンの後, 室温で反応さ せ，螢光顕微鏡下に検索した。

IgG, IgA，IgM 及び kappa と lambda chain 産生細胞は，それぞれ明確に染め別けられ，各グロブ リンはそれぞれ別個の細胞で産生されている。これらの細胞は虫垂では胃腸管の他部に於汁ると同様，粘 膜固有属に豊富に存在する形質細胞系或いはリンパ細胞系の細胞である。

Kappa 及び lambda 産生細胞は虫垂粘膜下に散在している。IgA 産生細胞は, 虫垂粘膜固有属の中て も特に腺窝の下部に压倒的に多く, 粘膜固有属全般に存在し, 又 $\mathrm{IgG}$ 産生細胞は粘膜固有属に存在して 牤り，炎症が進行した時期には粘膜固有属の深部に及ぶ。 IgM 産生細胞は粘膜上皮に接して分布してい 
るが，粘裳上皮からの遊出毛認められる。

それぞれの細胞類の比率をみると, kappa と lambda chain 産生細胞は如何なる時期でもほぼ $3: 2$ の 比率を示す。又 $\operatorname{IgA}$ 産生練胞は如何なる時期にも圧倒的に多く, 全グロブリン産生細胞の $80 \%$ 以上にみ られる。急性炎症の初期には IgM 産生細胞が 2 3 倍に增加を示し, 進行期及び化膿期には IgG 産生 細胞が增加を示すことを確認した。

\section{論文審査の結果の要旨}

溃光抗体法特に二重染色法を用いて, 脾, リンパ節，虫垂粘膜に括ける $\operatorname{IgG}, \operatorname{IgA}, \operatorname{Ig} M$ と，共通の subunit であるk 扣よび入 $\lambda$ chain の分布について検索した。抗血清はすべて自ら分離作成し，それぞ れ FITC, TRITC で標識して組織染色に用いた。

種々の組合せによる螢光抗体二重染色を観察した結果，1） k-chain, $\lambda$-chain 含有細胞の比率は, ぞの

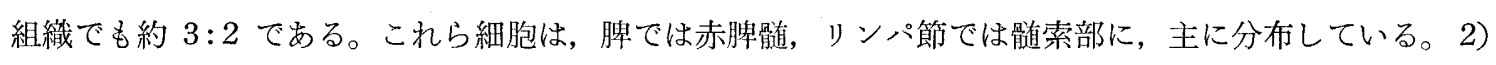

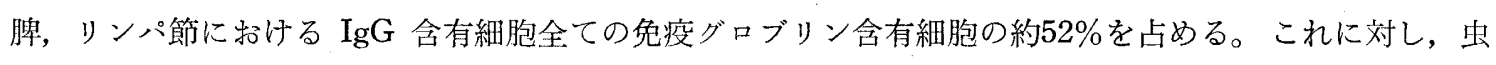
垂粘膜では, IgA 含有細胞が非常に多く約 $80 \%$ を占める。3） IgM 含有細胞は主に粘膜上皮に近接して 分布し，急性虫垂炎の初期に最も多い。 $\operatorname{IgG}$ 含有細胞は主に腺简下部および血管周囲に認められ，炎症の 進行につれて增加し，固有層深部にも出現してくる。4） IgM 抽よび IgA は粘膜上皮層を通して管内に 放出または分泌される像を認めるが，IgGではみられない。5）一つの免疫グロブリン含有細胞あるいは 同一リンパ濾胞内には，同時に 2 種以上の免疫グロブリンが出現しないのが原則である。また $\mathrm{K}$ 型ある いは $\lambda$ 型のいずれか一種しか存在しないことなどを新しく見出した。

よって，本論文は医学博士の学位論文として価值あるものと認める。 